\title{
IDEOLOGI ARGUMEN-ARGUMEN KEAGAMAAN TRADISI LINGKARAN HIDUP DALAM KITAB KUNING
}

\author{
Iswahyudi \\ Institut Agama Islam Negeri Ponorogo \\ Email: yudi_prapto@yahoo.com \\ Udin Safala \\ Institut Agama Islam Negeri Ponorogo \\ Email: udinsafa19@gmail.com
}

\begin{abstract}
This article will show that the implementation of the Javanese Islamic tradition in the form of the ritual of the life cycle (life circle) is the implementation of the ideology of Shāfí⿴\zh11⿰ developed by his followers (așhāb). The ideology was then known as the ideology of ashāb alshäfiryah. The ritual of the life in the form of a birth ritual (metu), marriage (manten) and death (mati) has been mentioned in the classic Islamic book (kitab kuning). Allegations that Javanese Islam as syncretic Islam and the adoption of Hindu and Buddhist traditions are wrong. The ritual of the life circle as shown in this article is emerging from within Islam itself as an embodiment of the interpretation of Islamic doctrine. The reseacher gets this conclusion after doing a research of various classic Islamic books that explain the ritual of the life circle. To find out the conclusion, the reseacher used the ideological criticism of Pierre F. Bourdieu. This article, therefore, rejects the views of outsiders such as Geertz, Beatty and Mulder, who explain that the ritual of Javanese Muslim is impure doctrine of Islam.
\end{abstract}

Keywords: Slametan; aṣhāb al-shāfirìyah; agent; contestation.

\section{Pendahuluan}

Para peneliti melihat tradisi Islam Jawa secara peyoratif. Mereka menganggap bahwa tradisi Islam Jawa adalah sumbangan dari berbagai unsur non-Islam. Akibatnya, para peneliti, yang ratarata sebagai outsider, melihat tradisi Islam Jawa dalam pandangan 
yang berbeda. Clifford Geertz, ${ }^{1}$ Andrew Beatty, ${ }^{2}$ dan Niels Mulder ${ }^{3}$ misalnya menganggap bahwa tradisi Islam Jawa berasimilasi dengan ajaran Hindu, Buddha dan Animisme. Menurut mereka, Islam Jawa adalah sinkretik, di mana Islam hanyalah sebagai kulit luarnya saja. ${ }^{4}$ Hodgson berbeda dengan Geertz, Beatty dan Mulder, di mana ia mengatakan bahwa anggapan Islam Jawa sebagai Islam yang dipengaruhi unsur luar semacam Hindu adalah keliru. Sementara Mark R. Woodward melihat hubungan Islam dengan tradisi Jawa bersifat simbiotik. Hubungan keduanya saling mengambil dan menerima. ${ }^{5}$ Mendukung Woodward, Nur Syam menyatakan bahwa tradisi Islam Jawa bersifat kolaboratif. Ciricirinya adalah penerimaan unsur-unsur budaya Jawa yang tidak bertentangan dengan Islam dan menguatkan Islam dengan argumentasi-argumentasi keagamaan berdasarkan perspektif elitelit lokal berdasarkan teks-teks agama yang diyakini. Nur Syam menyebut hubungan ini dengan istilah "Islam Kolaboratif".

Dua kelompok peneliti tersebut, kelompok Geertz dan Mulder serta kelompok Hodgson, Woodward dan Nur Syam, sama-sama melihat Islam tidak dalam perspektif inti, yaitu bahwa dalam Islam telah muncul berbagai pendapat yang mendorong seseorang untuk melakukan tindakan keagamaan yang kemudian disebut dengan "Islam Jawa". Pendapat-pendapat tersebut sejatinya dapat dilacak akar ideologisnya dalam kitab kuning, sebuah kitab yang banyak menjadi referensi sebagian besar penduduk Indonesia. Pencarian ideologi keagamaan dalam kitab kuning inilah yang terlupakan oleh para peneliti tersebut. Bukti para peneliti tidak merujuk argumen-

\footnotetext{
${ }^{1}$ Clifford Geertz, Abangan, Santri, Priyayi dalam Masyarakat Jawa (Jakarta: Pustaka Jaya, 1981).

2 Andrew Beatty, Variasi Agama di Jawa: Suatu Pendekatan Antropologi, terj. Achmad Fedyani Saefuddin (Jakarta: PT. Raja Grafindo Persada, 2001).

${ }^{3}$ Niels Mulder, Agama, Hidup Sehari-hari dan Perubahan Budaya (Jakarta: Gramedia Pustaka Utama, 1999).

${ }^{4}$ Dalam tradisi sinkretik, telah terjadi penggabungan berbagai unsur seperti antara Islam, Buddha, Hindu, Animisme dan lain-lain. Penggabungan tersebut menghasilkan unsur yang lebih dominan. Dalam hubungan Islam dan tradisi Jawa, Islam lebih mendominasi atau dikalahkan oleh tradisi Jawa. Lihat Nur Syam, Islam Pesisir (Yogyakarta: LKiS, 2005), 11.

${ }^{5}$ Mark R. Woodward, Islam in Java: Normative Piety and Mysticism in the Sultanate of Yogyakarta (Ann Arbor: UMI, 1989).

${ }^{6}$ Nur Syam, Islam Pesisir, 290-291.
} 
tasi inti Islam Jawa yang termaktub dalam kitab kuning dapat dilihat dalam beberapa hal.

Pertama, varian-varian Islam yang dimunculkan oleh Geertz dengan Islam sinkretik, Woodward sebagai Islam akulturatif dan Nur Syam dengan Islam kolaboratif telah melupakan sejarah ide (bistory of ideas) $^{7}$ atau asal-usul gagasan dari para subjek yang diteliti. Para subjek hanya memaparkan keyakinannya, namun tidak dimintai penjelasan mengenai landasan argumentasi keyakinannya tersebut. Kedua, tradisi Islam Jawa mengalami kontinuitas yang panjang, ditularkan dari satu generasi ke generasi berikutnya dan melewati berbagai kritik tajam kepadanya. Hal ini menunjukkan adanya basis ideologi pengetahuan yang kuat dalam diri pelakunya. Ketiga, baik Geertz, Mulder, Hodgson, Woodward dan Nur Syam melihat peranan kelompok abangan sebagai agen bagi pelestarian Islam Jawa yang penting. Geertz dan Mulder melihat abangan di pedesaan, sementara Nur Syam di pesisir. Peranan abangan di posisikan berdiri sendiri dengan kognisi keagamaan terpisah dengan elit agama. Padahal, di balik tindakan abangan, ada legitimasi elit agama di belakangnya. Hanya saja legitimasi tersebut tidak tertransformasi secara sempurna kepada kelompok abangan. Elit agama ini menurut Endang Turmudi memiliki dua hal, yaitu ilmu agama yang luas dan berasal dari keluarga berada. ${ }^{8}$ Geertz, ${ }^{9}$ Horikoshi ${ }^{10}$ dan peneliti lain menyebut elit agama ini dengan kiai. Dalam masyarakat yang dianggap tradisional oleh para peneliti, kiai mewarisi keilmuan tradisional, yaitu penguasaan kitab kuning.

Penelitian ini berusaha untuk mencari jawaban atas hal-hal berikut. Pertama, bagaimana pandangan kitab kuning terhadap pelaksanaan tradisi Islam Jawa lingkaran hidup (life circle) manusia?

\footnotetext{
${ }^{7}$ Sejarah ide mencuat setelah Michel Foucault menerbitkan karyanya The Order of Things, sebuah karya yang menjelaskan kesadaran orang-orang Eropa menyongsong renaissance. Dalam bukunya, Foucault melihat pentingnya pencarian asal usul berhentinya ide masyarakat Eropa. Baca Michel Foucault, The Order of Things: An Archaeology of the Human Sciences (London: Tavistock Publication, 1974).

${ }^{8}$ Endang Turmudi, Perselingkuhan Kiai dan Kekuasaan (Yogyakarta: LKiS, 2004), 95.

9 Clifford Geertz, "The Javanese Kijaji: The Changing Role of a Cultural Broker”, dalam Comparative Studies in Society and History, Vol. 2, No. 2 (1960), 250256.

${ }^{10}$ Hiroko Horikoshi, Kiai dan Perubahan Sosial (Jakarta: P3M, 1987).
} 
Kedua, ideologi keagamaan apa yang ada dalam kitab kuning ketika menjelaskan hal-hal yang berkaitan dengan tradisi Islam Jawa lingkaran hidup? Ketiga, siapakah para agen yang mempertahankan ideologi kitab kuning tentang tradisi Islam Jawa lingkaran hidup dalam masyarakat?

Untuk menjawab masalah tersebut, penelitian ini menggunakan pendekatan kualitatif, yaitu sebuah penelitian untuk mencari makna di balik sebuah pandangan dalam melihat masalah atau situasi. Metode yang digunakan tidak tunggal. Untuk menjelaskan pandangan kitab kuning tentang tradisi Islam Jawa dalam bentuk ritual lingkaran hidup digunakan metode content analysis. Sementara untuk mengetahui ideologi yang mengiringi gagasan-gagasan kitab kuning tentang tradisi Islam Jawa ritual lingkaran hidup, serta agen-agen dari ideologi tersebut, digunakan metode kritik ideologi Pierre F. Bourdieu. Sedangkan data primernya adalah kitab kuning seperti Sullam al-Tawfíq, Bäjūrì, al-Iqnà, Bujayrimì, al-Muḅarrar, Minhäj alṬälibin, Faț̣ al-Mu'in, Sharḅ Minhäj, Fath al-Wabhäb, Bughyat alMustarshidìn, I'ānat al-Tälibìn, Tawshīh 'alā Ibn Qäsim, Jam' al-Jawāmi', al-Ashbāh wa al-Nažāir, Kifāyat al-Akhyār, al-Majmū', dan lain-lain.

\section{Kitab Kuning dan Ritual Lingkaran Hidup}

Pandangan Geertz tentang model for bagi suatu tindakan keagamaan masyarakat Jawa menarik perhatian para intelektual. Pembagian sosial yang dibuatnya tentang santri, abangan dan priyayi dalam masyarakat Jawa tidak merefleksikan pembagian yang tepat. Dalam masalah tindakan kehidupan orang Jawa, kelompok abangan tidak selalu melakukan tindakan dan motif yang berbeda dengan kelompok santri. Kelompok santri justru kadangkala memperkuat terhadap tindakan yang dilakukan oleh kelompok abangan. ${ }^{11}$ Tindakan keagamaan memiliki dimensi lebih kompleks dari hanya sekadar fakta-fakta yang tampak sebagaimana dalam kajian sosiologis atau antropologis. Hal ini tampak dari ketidak jeliannya dalam membuat tipologi dengan mencampur antara

\footnotetext{
11 Geertz mendapat kritik dari Hodgson dan Nurcholish Madjid sebagai intelektual yang bias kolonial dan pandangan modernis. Lihat Madjid, "Mencari Akar-Akar Islam bagi Pluralisme Modern: Pengalaman Indonesia", dalam Mark R. Woodward (ed.), Jalan Baru Islam: Memetakan Paradigma Mutakhir Islam Indonesia, terj. Ihsan Ali-Fauzi, cet. 1 (Bandung: Mizan, 1998), 95. Lihat pula Marshall G. S. Hodgson, The Venture of Islam, Vol. 2 (Chicago: University of Chicago Press, 1974), 552.
} 
tipologi keagamaan seperti santri dengan tipologi strata sosial kehidupan dan ekonomi seperti priyayi. Dalam beragama, faktanya, banyak ditemui seorang priyayi yang santri sekaligus banyak pula seorang priyayi yang abangan. Masalah ini menjadi kian rumit ketika Geertz menganggap bahwa priyayi berasal dari kelompok birokrasi, santri dari pedagang perkotaan dan abangan dari kelompok petani pedesaan. ${ }^{12}$

Masyarakat Jawa pedesaan bagi Geertz dianggap bukan santri. Para santri yang dianggap "tradisionalis"13 dalam masyarakat pedesaan justru memiliki peran penting dalam melanggengkan tindakan yang oleh antropolog seperti Geertz dianggap sebagai sinkretisme. Para santri yang kebanyakan adalah petani, bukan pedagang seperti ungkapan Geertz, memberi justifikasi argumentasi keagamaan bagi tindakan keagamaan masyarakat Jawa. Namun, jika dihubungkan dengan masalah bias kolonial dan modernis, Geertz memiliki sisi benarnya juga. Apa yang dilakukan oleh kelompok santri di pedesaan sebagai pendukung keberislaman orang Jawa adalah merupakan representasi dari kelompok yang dianggap "tradisionalis" di atas. Mereka adalah masyarakat yang dianggap berlawanan dengan tipologi modernis. Kelompok tradisionalis tersebut rata-rata didominasi oleh anggota organisasi Nahdlatul Ulama (NU).

Justifikasi yang diberikan oleh kelompok santri ini biasanya berdasarkan argumentasi kitab kuning. Bagi kelompok masyarakat

12 M. Syafi'i Anwar mengutip pernyataan Geertz tersebut sebagai berikut. "Abangan mewakili suatu sikap yang menitik-beratkan pada aspek-aspek animistis dari sinkretisme Jawa yang menyeluruh dan secara luas dihubungkan dengan unsur petani; santri mewakili suatu sikap yang menitik-beratkan pada aspek-aspek Islam dari sinkretisme tersebut dan umumnya dihubungkan dengan unsur-unsur dagang (juga pada unsur-unsur tertentu di kalangan petani); dan priyayi yang sikapnya menekankan pada aspek-aspek Hindu dan dihubungkan dengan elemen-elemen birokratik." Lihat M. Syafi'i Anwar, Pemikiran dan Aksi Islam Indonesia: Sebuah Kajian Politik Cendekiawan Muslim Orde Baru (Jakarta: Paramadina, 1995), 262.

13 Kata "tradisionalis" ini sebenarnya kurang tepat digunakan, karena tipologi tradisionalis saat ini sudah mulai mencair. Pondok pesantren yang awalnya dianggap tradisionalis, saat ini menunjukkan gejala sikap modern dan moderat. Para santri bersarung mampu memahami bahasa asing dengan baik serta penguasaan teknologi komunikasi yang mumpuni. Kata "tradisionalis" digunakan untuk menghubungkan pemikiran dalam definisi lama dengan definisi yang sudah mulai mencair sehingga gagasan penulis bisa dipahami. 
Jawa NU, kitab kuning menempati posisi penting karena beberapa alasan. Pertama, kitab kuning diyakini sebagai sumber terpercaya untuk rujukan bagi tindakan keagamaan. Di dalam kitab kuning terdapat tradisi sanad (transmisi keilmuan) yang jelas. Transmisi keilmuan inilah yang mengakibatkan masyarakat NU mengikuti mazhab sebagai jaminan transmisi keilmuan. Mazhab dibangun oleh para mujtahid yang diakui keilmuannya. Para mujtahid merumuskan pendapatnya berdasar riwayat-riwayat yang sahih dari nabi. Kedua, pendapat-pendapat mujtahid tersebut dicantumkan dalam karya-karya mereka yang kemudian disebut kitab kuning. ${ }^{14}$ Berdasar dua argumen tersebut, masyarakat NU selalu menyuarakan pentingnya "mengaji" kepada guru yang memiliki sanad keilmuan. Warga NU menyakini bahwa sanad tersebut bersambung kepada penyebar Islam awal di Indonesia, Walisongo. ${ }^{15}$ Walisongo terutama Sunan Kalijaga (abad ke-16) adalah idola masyarakat Jawa. Banyak tindakan keagamaan masyarakat Jawa NU yang dilandaskan pada Sunan Kalijaga ini. Sunan Kalijaga dianggap oleh Geertz adalah sosok penyebar agama yang menjembatani dua kebudayaan tinggi, dua epos sejarah dan dua agama besar; Hinduisme-Budhhisme. Kalijaga menerapkan sistem damai dan bergandengan dengan budaya. Hal ini berbeda dengan Sidi Lahsen Lyusi (abad ke-17) di Maroko yang bersifat oposisional dengan budaya lokal sehingga tampak purifikatif. ${ }^{16}$

Dalam kitab kuning berisi banyak penjelasan tentang tindakan manusia. Ini berarti kitab kuning banyak menjelaskan tentang fiqh yang diterjemahkan sebagai ilmu yang membahas tentang hukumhukum sharí'ah mengenai tindakan manusia (mulai bangun tidur hingga tidur kembali) yang dicari argumentasinya dari dalil-dalil terperinci. ${ }^{17}$ Karena sifatnya yang terperinci, kitab kuning banyak menjelaskan berbagai pendapat para ulama yang tidak seragam,

\footnotetext{
14 Tim Aswaja NU Center PWNU Jawa Timur, Khazanah Aswaja: Memahami, Mengamalkan dan Mendakwabkan Ablussunnah wal Jama'ah (Surabaya: Aswaja Center NU Ponorogo, 2016), 200.

15 Ibid., 460.

${ }^{16}$ Nurcholish Madjid, Islam Doktrin dan Peradaban: Telaah Kritis tentang Masalab Keimanan, Kemanusiaan, dan Kemodernan, cet. 4 (Jakarta: Yayasan Paramadina, 2000), 542.

17 Muhammad Shaṭā al-Dimyāṭī, I 'ànat al-Ṭalibin, Vol. 1 (Singapura: Sulaiman Mar'i, t.th.), 14.
} 
walaupun dalam satu mazhab. ${ }^{18}$ Keberanian berbeda pendapat para ulama disebabkan kebenaran fiqh yang bersifat interpretatif dan bersifat zanni, di mana kemungkinan yang dianggap memiliki potensi lebih kuat sebagai yang benar. ${ }^{19}$

Kitab-kitab kuning tersebut lebih banyak ditransmisikan melalui lembaga pesantren. Tidak salah jika Zaehner menyebut lembaga pesantren sebagai pelestari bagi mistisisme Hindu Muslim. ${ }^{20}$ Yang kurang tepat dari Zaehner adalah penghukuman yang diberikan, sebagaimana Geertz, terjebak dalam satu pandangan tentang Islam, yaitu Islam modernis, untuk melihat Islam seperti yang diamalkan oleh orang Jawa NU. Alumni-alumni pesantren tersebut, dalam forum-forum bahth al-masäil (forum untuk membicarakan masalah-masalah agama) selalu mencari argumen-argumen dalam kitab kuning untuk membenarkan praktik-praktik ritual life circle orang Jawa sekaligus mengoreksinya jika dianggap tidak sesuai dengan kitab kuning.

1. Ritual Kelahiran (Metu)

Kitab kuning mengupas masalah kelahiran dalam tempat yang berbeda-beda. Kitab Fath al-Qarïb misalnya memasukkan masalah menyusui dan masalah pengasuhan dalam bab perkawinan. Hal ini disebabkan karena kelahiran adalah implikasi dari pernikahan. Namun, dalam masalah ritual aqiqah (menyembelih dua kambing untuk bayi laki-laki dan satu ekor kambing untuk bayi perempuan) dimasukkan dalam bab penyembelihan, qurban dan makanan. Sedangkan dalam masalah mandi setelah melahirkan termasuk dalam pembahasan yang mewajibkan mandi karena wilädah atau melahirkan. ${ }^{21}$ Pembahasan yang terpencar-pencar dalam kitab kuning dapat dimengerti karena berhubungan dengan keterkaitan pembahasan dengan hukum yang mengitarinya.

Pertama, slametan ketika hamil (nelani, mitani dan brokoban). Orang Jawa melakukan slametan di saat usia kandungan telah

\footnotetext{
${ }^{18}$ Inilah yang membedakan antara fiqh dengan usul fiqh. Fiqh bersifat terperinci, sementara usul fiqh bersifat global.

19 Zanni adalah lawan dari shakk, yaitu seimbang antara dua hal, baik kuat atau lemah. Lihat Ahmad b. Muḥammad al-Dimyāṭ̂, Heāshiyat al-Dimyātì 'alà Sharḥ alW araqät (Surabaya: al-Hidayah, t.th.), 6.

${ }^{20}$ R.C. Zaehner, Mistisisme Hindu Muslim, terj. Suhadi, cet. 1 (Yogyakarta: LKiS, 2004).

21 Muḥammad b. Qāsim al-Ghazzī, Sharḥ Fatḥ al-Qarīb al-Mujīb (Surabaya: alHidayah, t.th.).
} 
mencapai usia tiga bulan (dalam hitungan Jawa). Orang Jawa menyebutnya dengan nelani atau wilujengan nigani dengan hidangan sekul punar. ${ }^{22}$ Bagi orang Jawa, ritual ini berkaitan dengan harapan bahwa bayi dalam kandungan akan mendapatkan nasib yang baik di kemudian hari. Dalam Islam diketahui suatu tahapan-tahapan proses kejadian manusia yaitu 40 hari dalam bentuk air mani, 40 hari dalam bentuk segumpal darah dan 40 hari menjadi segumpal daging. Pada fase ini, janin telah berusia 120 hari atau empat bulan dalam hitungan bulan Masehi. Namun, orang Jawa menyebut empat bulanan itu dengan neloni karena sudah lengkap telung lapan (selapan berjumlah 35 hari; oleh karena itu telung lapan adalah 105 hari; selapan adalah lima kali pasar, satu kali pasar adalah lima hari). Pada saat usia sudah mencapai 120 hari, Allah meniupkan ruh kepada janin serta menentukan takdir dalam hal rezeki, kematian dan keberuntungan atau kesengsaraan. Dalam konteks ini, apa yang dilakukan oleh orang Jawa dianggap sesuai dengan apa yang tercantum dalam kitab kuning al-Jämi al-Säghìr karya Jaläl al-Dìn alSuyūtì dalam Hadīth Nomor 2179. ${ }^{23}$

Setelah ritual nelani, orang Jawa mengadakan acara tingkeban yang dilaksanakan pada saat usia kandungan berumur tujuh bulan. Jika dalam nelani konsentrasi slametan pada keinginan untuk mendapatkan nasib atau takdir baik bagi anak, maka pada tingkeban ini adalah persiapan untuk kelahiran yang mudah, lancar dan sesuai dengan harapan. Dalam usia tujuh bulan, fisik-fisik bayi sudah sempurna. Ritual diadakan dengan membaca surat Yùsuf dan surat Maryam agar anak memiliki paras yang tampan seperti Nabi Yūsuf jika laki-laki dan paras yang cantik seperti Maryam jika perempuan. Bacaan-bacaan salawat dikumandangkan untuk meminta pertolongan dari Allah atas kemudahan kelahiran. Kata Ningkeban, di pihak lain, adalah simbol menutup bayi dan sang ibu dari pengaruh-pengaruh yang tidak baik (seperti hilangnya bayi, tidak lengkapnya anggota tubuh bayi, bertambahnya jari-jari dan lainlain). Ningkebi bayi dan ibunya maksimal sampai sang bayi keluar. Ningkebi mengandung doa pula agar bayi keluar dengan mudah, dan tidak perlu malu sebagaimana disimbolkan dalam ritual siraman dengan kelapa kuning, yang dimasukkan dari atas kain yang dipakai oleh calon ibu menuju bagian bawah kain atau

22 Nasi kuning dengan beberapa daging yang disukai.

${ }^{23}$ Jalāl al-Dīn al-Suyūṭī, al-Jāmi‘ al-Ṣaghìr (Beirut: Dār al-Kutub al-'Ilmīyah, 1990). 
pelemparan pisang yang telah dikupas ke luar (lapangan) oleh tokoh adat.

Doa adalah kegiatan yang disenangi Tuhan. "Mintalah kalian kepada-Ku, maka akan Aku kabulkan permintaamu". ${ }^{24}$ Abū Bakr Aḥmad al-Bayhaqī dalam karya Daläil al-Nubunwah menceritakan suatu hadīth bahwa Nabi Muhammad telah mendoakan bayi dalam kandungan Ummu Sulaym yang menjadi istri dari Abū Ṭalhah.

Bab tentang mendoakannya Nabi Muhammad atas kehamilan Ummu Sulaym dari Abū Ṭalḥah. Malam itu, Abū Ṭalḥah melakukan hubungan suami istri dengan Ummu Sulaym. Doa Nabi adalah, "Ya Allah, berkahilah untuk mereka berdua pada malam milik mereka ini". Periwayat hadith menjelaskan, bahwa Ummu Sulaym kemudian melahirkan seorang anak laki-laki yang diberi nama 'Abd Allāh. Perawi ḥadīth bercerita lagi, bahwa orang-orang menyebutkan bahwa 'Abd Allāh termasuk orang terbaik pada masanya. ${ }^{25}$

Kedua, masalah ari-ari. Setelah kelahiran, orang Jawa biasanya mengubur ari-ari ke dalam tanah. Anak laki-laki di sebelah kanan pintu rumah dan diletakkan di sebelah kiri pintu rumah apabila bayi berjenis kelamin perempuan. Kitab kuning memang tidak membicarakan bagaimana tata cara penguburan ari-ari. Dalam kitab kuning dijelaskan bahwa ari-ari memiliki hukum suci, bukan najis, sehingga memegang ari-ari tidak diperlukan untuk mencuci tangan sebagaimana menghilangkan najis. Kitab kuning menyebut ari-ari dengan istilah mashimab. ${ }^{26}$ Kitab kuning karya al-Ramlī, Nihāyat al-Mubtäj, menjelakan bahwa mashimah sunnah untuk dikuburkan. Ungkapan kitab Nibäyah adalah "disunnahkan menguburkan sesuatu yang terpisah dari manusia hidup yang apabila terpisah manusia tidak mati seketika". ${ }^{27}$ Bukankah ari-ari yang terhubung dengan tali pusar adalah bagian dari manusia? Pernyataan al-Ramlī memiliki kesamaan dengan kitab kuning Asnā

\footnotetext{
${ }^{24}$ Q.S. al-Mu'min [40]: 60.

25 Abū Bakr Aḥmad al-Bayhāqī, Dalāìl al-Nubuwwah, Vol. 6 (Kairo: Dār alHadīth, t.th.), 406.

26 Abī 'Abd al-Mu'ṭī Muhammad Nawawī, Käshifat al-Sajā (Semarang: Usaha Keluarga, t.th.), 34.

27 Shams al-Dīn Muḥammad b. Abī al-'Abbās Aḥmad b. Hamzah b. Shihāb alDīn al-Ramlī, Nihāyat al-Muhtāj ilā Sharḥ al-Minhäj, Vol. 2 (Lebanon: Dār al-Fikr, t.th.), 494-495.
} 
al-Matālib karya Abū Yahyā Zakariyyā al-Anșārī yang menghukumi sunnah menguburkan ari-ari, hanya keduanya berbeda dalam pengungkapan masalah kesunnahannya. Baik Nibāyah maupun Asnā al-Matālib memasukkan masalah ari-ari ke dalam masalah mashimah. ${ }^{28}$ Perbedaannya adalah bahwa kitab Nibāyat al-Muḅtäj menggunakan kalimat "yusann-u" untuk menunjukkan hukum sunnah menguburkan mashimah, sementara kitab Asnā al-Matälib menggunakan kalimat "yustaḩabb-u". Dua kalimat ini memiliki pengertian yang sama, hanya kalimat "yusann- $u$ " lebih memiliki penekanan dari pada "yustababb-u".

2. Ritual Pengantin (Manten)

Ritual lain yang dianggap sakral oleh orang Jawa adalah ritual pengantin. Pengantin dalam Islam disebut dengan nikah. Hampir semua kitab kuning menempatkan pembahasan tentang nikah dalam satu bahasan khusus. Kitab kuning Fath al-Mữn mendefinsikan nikah sebagai suatu transaksi yang mengakibatkan sahnya melakukan hubungan suami istri melalui perantaraan lafaz nikēh. atau tajwi\%. Nikah secara bahasa dimaknai sebagai kumpul atau dempet. $^{29}$

Di antara ritual pernikahan adalah sebagai berikut. Pertama, hitungan calon pengantin dan hari pernikahan. Hitungan ini bagi orang Jawa adalah untuk kebahagiaan calon pengantin dan orang tua pengantin. Banyak kasus orang Jawa menghentikan proses perjodohan akibat ketidaksesuaian dengan proses numerologi Jawa. Tidak hanya untuk masalah perjodohan suami istri, penentuan hari untuk ritual pernikahan juga berdasarkan petungan yang dianggap dapat menjadikan acara berjalan lancar. Kitab kuning Ghäyat Talkhiss al-Murād min Fatäwā Ibn Ziyäd menyatakan bahwa sesungguhnya meyakini petungan atau hari-hari tertentu dapat mendatangkan kebaikan untuk semisal acara akad, hukumnya adalah dilarang. Namun kitab Ghāyat Talkhis memaparkan pandangan lain dari ulama yang berbeda pendapat. Ulama tersebut adalah Ibn al-Farkāḥ. Ibn al-Farkāh, menurut kitab Ghāyah, mengambil dari pendapat al-Shāfíì yang menggantungkan

\footnotetext{
28 Abū Yahyyā Zakariyyā al-Anșārī, Asnā al-Matālib Sharḥ Rawd al-Ṭälib, Vol. 1 (Beirut: Dār al-Kitāb al-Islāmī, t.th.), 313.

${ }^{29}$ Zayn al-Dīn al-Malībārī, Fatḥ al-Mưinn (Bairut: Dār al-Kitāb al-Islāmī, t.th.), 9798.
} 
masalah pelarangan pada itiqäd atau keyakinan seseorang baik oleh ahli penghitung (dukun) maupun si peminta hitungan. Jika seseorang, dengan hitungan tersebut, meyakini bahwa hitungan tersebut hanyalah bagian dari upaya pemahaman seseorang atas kebiasaan-kebiasaan yang dilakukan Allah terhadap sesuatu maka diperbolehkan. Pendapat ini membolehkan penentuan hari baik dalam transaksi dan lain-lain selama seseorang tetap berkeyakinan bahwa Allah adalah penentu semua hal. Hanya saja seseorang mengetahui bahwa Allah membuat hukum alam atau sunnat Alläh yang berlaku biasanya secara konsisten. Secara ringkas, ungkapan kitab Ghäyah sebagai berikut.

Ibn al-Farkāh berpendapat yang diambil dari perkataan Imām alShāfi'̄i yaitu jika seorang ahli nujum [perbintangan] mengatakan dengan kondisi masih meyakini bahwa tidak ada yang mampu memberi efek kepada sesuatu kecuali Allah dan ia meyakini bahwa Allah memiliki kebiasaan-kebiasaan [sunnat Allah], satu hal terjadi karena hal lain, dan semuanya tidak akan terjadi kecuali Allah menghendaki. Jika ini yang dipegangi, maka menurutku [menentukan hari baik dengan hitungan-hitungan Jawa] adalah tidak menjadi masalah dalam agama. Yang menjadi masalah adalah ketika seseorang berkeyakinan bahwa hitungan tersebut adalah penentu. ${ }^{30}$

Kitab Tuhfat al-Murid menyebut orang yang meyakini model terakhir ini (Allah sebagai penentu segalanya) sebagai al-İmàn almunjī (imannya orang yang selamat), yaitu selamat dari predikat kafir atau musyrik. ${ }^{31}$

Kedua, kirim leluhur (manggulan). Sebelum prosesi perkawinan dilakukan, orang Islam Jawa mengadakan tablil sebagai kirim dunga atau kirim doa atau manggulan kepada para leluhur yang telah meninggal. Kirim leluhur adalah bagian dari ritual di mana orang Jawa mengingat para orang tua dan saudara yang telah mendahului mereka. Oleh karena itu, dalam kirim leluhur, tidak hanya orang tua kandung tetapi juga saudara-saudara yang memiliki hubungan darah dengan keluarga pengantin dari arah bapak (laki-laki) atau dari arah ibu (perempuan) diikutkan dalam rangkaian doa tersebut.

\footnotetext{
30 'Abd al-Raḥmān b. Maḥammad b. Husayn Bā'alawī, Ghāyat al-Talkhịs al-Murād min Fatāwā Ibn Ziyād (Beirut: Dār al-Fikr, t.th.), 206.

31 Ibrāhīm al-Bayjūrī, Tuhfat al-Murìd Sharḥ Jauhar al-Tawhìd (Lebanon: Dār alKutub al-'Ilmìyah, 2004), 57.
} 
Secara umum, kirim leluhur terdiri dari beberapa rangkaian, yaitu: Pertama, penyampaian tawassul kepada para nabi, ulama, dan juga orang-orang yang telah membuka kampung tempat di mana kirim leluhur dilakukan. Kedua, ritual kirim leluhur dengan membaca berbagai ayat suci al-Qur'ān seperti pembacaan surat alIkhlāṣ, dan mu'amwidhatayn (surat al-Falaq dan al-Nās); salawat, istighfär, tasbiḥ, dan pembacaan là iläha illà Alläh. Ketiga, doa, yaitu meminta kepada Allah agar pahala dari semua pembacaan yang dilakukan diberikan pula kepada leluhur yang telah disebutkan dalam tawassul.

Kitab kuning Fatāwā al-Ramlì menjelaskan bahwa mengirimkan pahala Fätibah untuk para nabi dan juga untuk orang yang sudah meninggal diperbolehkan dan bahkan termasuk sunnah hukumnya. Hal ini dikiyaskan sebagaimana membaca salawat kepada Nabi Muhammad. Kitab Fatâwà al-Ramlì menyatakan tradisi kirim Fätihah untuk nabi telah menjadi kebiasaan para ulama muta'akbirin. ${ }^{32}$ Kebiasaan yang dilakukan ini didasarkan pada hadìth Nabi Muhammad, bahwa segala hal yang dipandang baik oleh orangorang Islam, maka menurut Allah juga dipandang baik. Teks kitab Fatāwà al-Ramlì adalah sebagai berikut:

Al-Ramlī pernah ditanya tentang hukum membaca al-Qur'ān dan pahalanya dihadiahkan untuk Nabi Muhammad sebagai contoh. Pahala tersebut disampaikan ke haribaan Nabi Muhammad atau sebagai upaya untuk menambah kemuliaan beliau, atau ditujukan langsung untuk beliau atau motif-motif lain sebagaimana kebiasaan yang telah berlangsung di masyarakat. Apakah kebiasaan tersebut diperbolehkan, disunnahkan yang berarti pelakunya mendapat pahala atau justru tidak diperbolehkan? Sedangkan orang yang melarang tindakan tersebut berargumen bahwa tindakan tersebut dilarang karena tidak ada dasarnya dalam agama, dan tidak seharusnya tradisi yang tidak ada dalilnya ini diarahkan kepada Nabi Muhammad yang mulia, kecuali untuk segala hal yang ada dalilnya seperti salawat kepadanya. Jika salawat boleh sebagai wasilah, ${ }^{33}$ apakah ini berpahala atau tidak? Al-Ramlī menjawab bahwa tradisi masyarakat tersebut boleh dan disunnahkan karena diqiyaskan dengan membaca salawat untu Nabi Muḥammad-sampai al-Ramlī mengatakan—sungguh sekelompok ulama muta'akbirin telah membolehkan tradisi ini dan

\footnotetext{
32 Ulama muta'akbirin adalah ulama yang hidup setelah tahun 300 Hijrīyah.

${ }^{33}$ Dari kata wasilab inilah tradisi tawassul diucapkan (keterangan peneliti).
} 
dilakukan pula oleh masyarakat, karena apa yang dipandang baik oleh orang-orang Islam maka diangap baik pula oleh Allah. ${ }^{34}$

Pandangan kitab Fatâwā al-Ramlì, akan semakin jelas dengan uraian yang diberikan oleh kitab Radd al-Mubtär 'alā al-Durr alMukhtär. Kitab ini menjelaskan bahwa bacaan Fätiḩah yang dibacakan untuk orang yang sudah meninggal maka pahala tersebut akan sampai kepada orang yang dimaksud. Kitab ini berisi masalah perdebatan tentang sampainya pahala yang dihadiahkan untuk orang yang sudah meninggal dengan eksemplar Ibn Taymīyah. Bagi Ibn Taymìyah, pahala berbagai bacaan yang dihadiahkan untuk Nabi Muhammad tidak akan sampai karena ini merendahkan derajat kenabian. Pahala akan sampai jika pahala yang dihadiahkan tersebut telah mendapatkan restu dari Nabi Muhammad langsung seperti bacaan salawat dan permohonan wasilah kepada beliau. Pandangan Ibn Taymìyah ditolak oleh al-Subkī dan lainnya. Menurut al-Subkī, pahala yang sampai kepada orang yang sudah meninggal, termasuk kepada Nabi Muhammad, tidak membutuhkan restu dari beliau. Ulama-ulama dari mazhab alShāfíī telah sepakat bahwa menghadiahkan pahala untuk orang lain termasuk kepada Nabi Muhammad diperbolehkan dan akan sampai. Jika untuk manusia biasa saja diperbolehkan, maka untuk Nabi Muhammad tentu lebih mulia dan lebih baik. ${ }^{35}$

3. Ritual Kematian (Mati)

Ritual terakhir dalam rangkaian orang Islam Jawa adalah ritual kematian. Seperti hanya ritual kelahiran sebagai awal mula manusia hadir di alam dunia, ritual kematian pun dilakukan. Bedanya adalah, jika ritual kelahiran dan ritual manten dirayakan dengan suka cita, maka ritual kamatian dilakukan dengan duka cita.

Pertama, ritual pungkur atau ungkur-ungkur. Setelah penguburan selesai, para pengantar pulang ke rumah masing-masing. Sebagian dari pengantar, terutama dari kerabat dan tetangga dekat, menuju ke rumah duka untuk melaksanakan ritual pungkur. Menu yang dibuat sebagai pelengkap ritual biasanya adalah tujuh macam sayursayuran seperti kacang panjang, bayam, kubis, kecambah dan lainlain hingga berjumlah tujuh bahan. Menu lainnya yang tidak

\footnotetext{
${ }^{34}$ Hāmish Fatāwā al-Ramlì dalam Ibn Hajar al-Makkī al-Haytamī, Fatāwà al-Kubrā al-Fiqhiyah, Vol. 3 (Mesir: 'Abd al-Hamd Ahmad Hanafi, t.th.), 125.

35 Ibn 'Ābidīn, Radd al-Muḥtār 'alà al-Durr al-Mukhtār, Vol. 2 (Mesir: Muṣtafāā alBāb al-Hạabī, 1966), 244.
} 
dilupakan adalah ingkung. Berbagai makanan tersebut dihidangkan bersama dengan nasi gunungan atau tumpeng yang dibelah menjadi dua. Dua buah tumpeng terbelah tersebut kemudian diletakkan secara bertolak belakang. Peletakan tumpeng demikian disesuaikan dengan ritual yang akan dilaksanakan.

Ritual pungkur, di samping sebagai doa agar orang meninggal dalam kondisi ḅusn al-khätimah, dimaksudkan pula sebagai sedekah kepada orang-orang yang telah membantu prosesi perawatan jenazah yang mencakup memandikan, mengkafani, menyalati, dan menguburkan sebagai suatu kewajiban umat Islam terhadap orang yang sudah meninggal. Tradisi ini (membuat makanan) tidak dilakukan oleh keluarga duka (anak atau suami dan istri), melainkan oleh para tetangga. Memberi makan kepada orang yang takziyah disebutkan oleh Fath al-Mu'in sebagai aspek yang dibenci (makrüb). Hukum yang diberikan oleh Fath al-Mu'in adalah dianjurkannya para tetangga untuk membantu keluarga yang sedang kesusahan dengan memasakkan makanan atau segala kebutuhannya dalam waktu sehari semalam. ${ }^{36}$ Lebih dari itu, tradisi takziyah biasanya selalu dibarengi dengan pemberian sesuatu kepada keluarga duka, seperti uang yang diletakkan dalam tempat yang ditutupi kain atau membawa beras. Hukum makrūh yang disebut Fatḥ al-Mu'in adalah adanya beban ganda bagi keluarga duka, yaitu kematian orang yang dicintainya dan pemberian sesuatu kepada orang yang melayat.

Ritual pungkur yang menghimpun antara doa dan pemberian makanan jika dimaksudkan untuk ditujukan kepada orang yang meninggal adalah sesuatu yang dianjurkan oleh kitab kuning Nibāyat al-Zayn. Kitab ini menjelaskan bahwa sedekah yang pahalanya ditujukan untuk orang yang meninggal adalah sesuatu yang diperintahkan oleh sharīah, namun cara ini haruslah sesuai dengan shari'ah serta tidak pula diikat oleh kondisi atau hari-hari tertentu seperti tujuh hari atau yang lainnya. ${ }^{37}$

Kitab Nibayat al-Zayn mensaratkan dua hal dalam ritual apa pun termasuk ritual pungkur, yaitu tidak bertentangan dengan sharíah. Sharīah yang dimaksud adalah pedoman-pedoman umum agama Islam seperti tidak ada unsur yang merusak terhadap akidah Islam, seperti shirk atau sesuatu yang dibenci dalam Islam seperti tabdhir

36 Al-Malībārī, Fatḥ al-Mu'in, 145.

37 Nawāwī al-Bantanī, Nihāyat al-Zayn (Beirut: Dār al-Kutub al-'Ilmīyah, 2002), 275. 
(berlebih-lebihan) dan melawan takdir Tuhan seperti menangis dengan merobek baju dan lain-lain. Nibayat al-Zayn juga mensyaratkan tanpa batasan hari-hari tertentu. Sedekah dan doa haruslah bersifat mutlak, di manapun, kapanpun dan dalam situasi apa pun. Harus diakui, tidak ada keterangan yang kaku untuk doa kepada orang yang sudah meninggal. Pembatasan atau qayd yang diungkapkan oleh Nihayyat al-Zayn dimungkinkan karena khawatir akan adanya perbuatan baru yang menyebabkan tashaddud atau pemberatan dalam ibadah. Hal ini ditandai dengan ungkapan Nihäyat al-Zayn berikutnya bahwa apabila qayd dimaksudkan sebagai kebiasaan saja, maka tidak menjadi masalah. ${ }^{38}$

Kitab kuning Qurrat al'Ayn mengatakan, apabila niat pemberian makan kepada orang yang bertakziyah dimaksudkan untuk memuliakan tamu serta menghibur diri dari musibah yang menimpanya atau juga untuk tujuan agar dapat menghilangkan rasa sedih yang menimpanya, maka pemberian ini bisa dianggap sebagai ibadah. Oleh karena itu, pelakunya akan mendapatkan pahala dari Allah sebagai wujud ketaatan kepada-Nya. Kitab Qurrat al-'Ayn secara tegas mengungkapkan pemberian itu secara mutlak tanpa batasan, termasuk apabila pemberian makanan dilakukan setelah mayat dikuburkan. ${ }^{39}$

Kedua, ritual ketiga, ketujuh, keempat puluh, keseratus, keseribu hari, dan tahunan pascakematian. Al-Nawawī al-Bantanī, sebagai orang asli Indonesia asal Tanara, Banten, menyadari bahwa ritual kematian seperti peringatan ketujuh, keempat puluh, keseratus dan keseribu hari kematian telah menjadi tradisi hampir seluruh masyarakat Islam Jawa. Al-Nawawī tidak melewatkan pembahasan masalah ini. Telah dijelaskan sebelumnya, al-Nawawī menganggap ritual dalam hitungan-hitungan ini adalah bagian dari tradisi yang diperbolehkan dalam agama. Al-Nawawī mengambil argumennya dari dua orang tokoh atoritatif dalam mazhab al-Shāfíī, yaitu Sayyid Aḥmad Zaynī Daḥlān dan Yūsuf al-Sumbulāwaynī. Lebih lengkapnya, al-Nawawì mengatakan:

Mengkhususkan sedekah untuk orang yang sudah meninggal pada hari-hari tertentu adalah bagian dari kebiasaan saja sebagaimana yang telah difatwakan oleh Sayyid Aḥmad Daḥlān.

\footnotetext{
${ }^{38}$ Ibid.

${ }^{39}$ Ismāîil b. al-Zayn, Qurrat al-'Ayn bi Fatāwā Ismāîl (t.t.: Maktabah al-Barakah, t.th.), 155.
} 
Telah berlaku tradisi ini di kalangan manusia dengan memberi sedekah untuk orang yang meninggal pada hari ketiga, hari ketujuh, hari kedua puluh, hari keseratus, dan untuk setiap tahunnya seperti telah dijelaskan oleh guru kami, Yūsuf alSumbulāwain̄̄. 40

Kitab kuning Fatāwà al-Fiqhiyah al-Kubrā karya Ibn Hajar alHaytamī menjelaskan sosok penting dalam tradisi tablī adalah Ṭāwūs. Namun, Ṭawūs tidak sendirian. Ada sosok lain yang berperan penting yaitu 'Ubayd b. 'Umayr. Jika Ṭāwūs adalah dari kelompok täbi'in, maka 'Ubayd b. 'Umayr diperkirakan adalah seorang sahabat, karena ia lahir pada masa Rasulullah dan hidup pada sebagian masa pemerintahan 'Umar b. al-Khaț̣āb. Dari sejarah ini dapat dikatakan bahwa hadīth-ḥadīth yang disampaikan oleh Ṭāwūs dari kalangan täbi'in dan 'Ubayd b. 'Umayr dari kalangan sahabat dapat dikatakan sebagai hadīth marf $\bar{u}$ ' (hadīth yang disandarkan kepada Rasulullah) atau hadīth mursal (hadīth yang rawi dari sahabat tidak ada atau gugur). Namun, jika hadīth mursal dan marfü tersebut didukung oleh hadīth-hadìth lain atau tidak bertentangan dengan hadīth saḥih maka mengamalkan hadīth mursal atau marfü‘ tersebut dibolehkan. Kebolehan mengamalkan hadīth seperti ini, menurut Ibn Hajar, disepakati oleh Mālik, Abū Ḥanīfah, al-Shāfíč́, dan Aḥmad. ${ }^{41}$

\section{Ideologi Kitab Kuning tentang Ritual Lingkaran Hidup}

Ideologi memungkinkan sebuah tindakan ditransformasikan secara kontinu. Michael Sastrapratedja menjelaskan bahwa ideologi minimal memiliki tiga hal. Pertama, mengandung penafsiran terhadap realitas masa lalu yang diarahkan untuk masa depan. Kedua, ideologi mengandung nilai atau sistem yang menolak nilai atau sistem lainnya. Ketiga, ideologi mengarahkan pada suatu tindakan untuk memperjuangkan nilai-nilai yang diyakini tersebut. ${ }^{42}$

1. Al-Shāfíc̄: Awal Pembentuk Habitus

Berbagai kitab kuning yang menjelaskan tentang ritual lingkaran hidup hampir seluruhnya dapat dirujukkan pendapat atau

\footnotetext{
40 Al-Nawawī, Nihāyat al-Zayn, 275.

${ }^{41}$ Ibn Hajar al-Haytamī, Fatawā al-Fiqhìyah, Vol. 3, 191.

42 M. Sastrapratedja, "Pancasila sebagai Ideologi dalam kehidupan Budaya", dalam Oetojo Oesman dan Alfian (eds.), Pancasila sebagai Ideologi dalam Berbagai Bidang Kehidupan Bermasyarakat, Berbangsa, dan Bernegara (Jakarta: BP-7 Pusat, 1991), 143-144.
} 
argumennya kepada al-Shāfí̄i. Dalam menjelaskan keabsahan diperbolehkannya menghitung hari baik dan buruk atau petungan misalnya, kitab kuning Ghāyat al-Talkhiss al-Murād min Fatāwā Ibn Ziyäd menjelaskan kebolehan petungan dengan catatan bahwa petungan tersebut tetap dilandaskan kepada kuasa Allah bukan sesuatu yang lain. Orang yang melakukan petungan harus tetap meyakini bahwa Allah adalah penentu segalanya. Pendapat inilah yang dipegangi oleh Ibn al-Farkāh dengan bukti perkataan dari alShāfi'î̀. Al-Shāfí' mengatakan bahwa sumber utama untuk menentukan bahwa ahli nujum shirik atau tidak adalah ketika keyakinan ahli nujum tersebut telah menafikan peran Allah. Kitab kuning Ghāyah menjelaskan bahwa al-Shāfi ${ }^{\prime} \overline{1}$ memboehkan hitungan atau petong asal keyakinan utama atas penentu nasib adalah di tangan Allah. Pandangan al-Shāfíci ini disampaikan oleh Ibn al-Farkāh. ${ }^{43}$ Demikian pula dalam menjelaskan masalah sampainya pahala yang disampaikan kepada orang yang sudah meninggal, tidak hanya masalah pahala sedekah, tetapi juga pahala al-Fätiḩah. Para pengikut al-Shāfíīi, seperti al-Ramlī, dengan jelas membolehkan dan menganggap bagus hadiah pahala ini. Pendapat al-Ramlī tersebut misalnya tercantum dalam kitab kuning Fatāwā alRamlì ${ }^{44}$ Tokoh lain dari pengikut al-Shāfíī yang membolehkan kirim pahala kepada orang yang sudah meninggal adalah Ibn Hajar al-Haytamī. Al-Nawawī al-Bantanī misalnya mengutip pandangan Ibn Hajar al-Haytamī tersebut dalam kitab Nibāyat al-Zayn ${ }^{45}$

Demikian pula dalam menjelaskan keabsahan ritual nelani dan mintani dalam tradisi kehamilan. Kitab kuning menyebutnya sebagai ungkapan rasa syukur dan karenanya disunnahkan untuk mengadakan perayaan (walimah). Orang Jawa memberi nama atas walimah ini dengan istilah slametan agar anak yang dikandung maupun untuk ibu yang akan melahirkan diberi keselamatan oleh Allah. Keabsahan walimah sebagai ungkapan rasa syukur diungkapkan oleh kitab kuning Fath al-Mu inn, salah satu kitab dalam mazhab alShāfí̄î, sebagai berikut.

Dan disunnahkan menghadiri undangan semua perayaan (walä'im) sebagaimana dilakukan dalam perayaan khitan (sunat untuk lakilaki), karena melahirkan dan selamatnya perempuan dalam proses

\footnotetext{
${ }^{43}$ Bā’alawī, Ghàyat al-Talkhìs, 206.

${ }^{44}$ Hāmish Fatāwà al-Ramlì dalam al-Haytāmī, Fatāwà al-Kubrā, Vol. 3, 125.

45 Al-Bantan̄i, Nihāyat al-Zayn, 193.
} 
kelahiran, karena baru datang dari berpergian, karena selesai membaca al-Qur'ān 30 juz. Menghadiri semua perayaan tersebut disunnahkan (mustahabbab). ${ }^{46}$

Dari cuplikan berbagai argumen kitab kuning di atas tampak bahwa pandangan al-Shāfíc̄ dan juga para penerus al-Shāfíc̄ sangat dominan. Walau demikian, argumen-argumen kitab kuning lebih banyak menampilkan pandangan dari pengikut al-Shāfí̄ ketimbang al-Shāfi'ì itu sendiri. Para pengikut al-Shāfi'i ini kemudian dikenal sebagai aṣ̣āb al-shäfi ìyah atau dikenal lebih pendek dengan sebutan al-shäfi iyah. Nama-nama yang dikenal seperti Ibn Hajar al-Haytamī, Ibn Hajar al-'Asqalānī, Muhyy al-Dīn Abū Zakariyyā al-Nawawī dan al-Ramlī, bahkan al-Nawawī al-Bantanī adalah pemuka penting dari mazhab al-Shāfi's̄'.

2. Mekanisme Ideologis

Al-Shāfi'ì memiliki dasar pokok dalam mengeluarkan hukum Islam, yaitu al-Qur'ān, Sunnah, Ijmā' dan Qijās (analogi). Meskipun demikian, untuk menyesuaikan perkembangan mazhab al-Shāfi ${ }^{\circ}$, para aş̣ab al-shäfícyah mengembangkan gagasan al-Shāfís̄ melalui ijtihad-ijtihad mereka. Para mujtahid sebagai penerus al-Shāfi'̄i adalah seperti: Pertama, mujtahid muntasib, yaitu mujtahid yang telah memenuhi kualifikasi untuk merumuskan hukum sebagaimana mujtahid mustaqil, namun ia belum mampu membuat suatu kaidah hukum sendiri, seperti al-Buwayț̄ dan al-Muzanī. Kedua, mujtabid muqayyad, yaitu mampu merumuskan hukum-hukum yang belum dijelaskan oleh al-Shāfí⿴\zh11̄ dengan berdasarkan kepada kaidah yang dibikin oleh mujtabid mustaqil, namun mujtabid muqayyad belum mencapai derajat mujtahid muntasib. Mereka adalah seperti Abū Ishāa al-Shirāzī, al-Mawardī, Muhammad b. Jarīr, Abī Naṣr dan Ibn Huzaymah. Ketiga, mujtahid tarjīh, yaitu yang memiliki kualifikasi dalam pemberian penilaian terhadap pendapat yang kuat dan lemah dari pandangan mujtahid mustaqil, atau antara pendapat para pengikut mujtahid mustaqil (aşhāb) atau antara pendapatnya mujtahid mustaqil dengan pendapat para așāab. Yang termasuk dalam kelompok mujtahid tarj̄̄h adalah al-Nawawī dan al-Rāfi ‘̄i. Keempat, mujtahid fatwā, yaitu yang dapat mengkategorikan, mengklasifikasikan berbagai pendapat di kalangan mazhab, dan mampu mengulas suatu pendapat dengan mengatakan bahwa suatu

46 Al-Malībārī, Fatḥ al-Mữn, 109. 
pendapat tersebut memiliki derajat lemah, kuat atau yang lainnya. Ulama yang masuk dalam kategori ini adalah seperti Ibn Hajar alHaytamī dan al-Ramlī. Ideologi al-Shāfi'i yang dikembangkan oleh așhāb al-shäficyah inilah yang menjadi pedoman tradisi ritual lingkaran hidup yang tercatat dalam kitab kuning.

\section{Agen Ideologi Kitab Kuning Ritual Lingkaran Hidup}

Agen adalah individu, subjek atau kelompok yang menjadi pengawal dari suatu gagasan atau ideologi agar dapat mempetahankan diri dari serangan ideologi lain. Posisi agen sangat menentukan bagi berkembangnya suatu ideologi. Posisi agen, oleh karena itu, berkelindan pada dua hal, yaitu mempertahankan dan mentransformasikan ideologi supaya diinternalisasi oleh banyak anggota. Posisi agen berarti menginternalisasikan ideologi dan sekaligus mengeksternalisasikannya. Semakin menyebar agen, semakin berpotensi ideologi tersebut meluas, namun semakin sedikit agen, semakin lambat pula persebarannya. Seperti ini pula yang terjadi pada mazhab, sama dengan ideologi, bisa bertahan di daerah Jawa atau Indonesia. Agen ideologi kitab kuning (așhāb alshäficiyah) terdiri dari dua macam, yaitu agen kelompok atau lembaga dan agen individual.

Agen kelompok atau lembaga terdiri dari organisasi NU, komunitas kultural (Yasinan ibu-ibu kampung, komunitas Dhikr Fida', komunitas Salawat Burdah, komunitas "Sorot" Salawat dan Ratib), komunitas Majlis al-Khidmah, komunitas Semaan al-Qur'ān Jantiko MANTAB, komunitas Salawat Nāriyah, komunitas Mafia Salawat, dan lain-lain), komunitas Gusdurian, dan pesantren.

Agen individual adalah orang yang secara personal memiliki visi untuk melakukan internalisasi dan eksternalisasi ideologis. Usaha-usaha mereka dilakukan dengan cara yang beragam. Penanaman ideologi dapat dilakukan secara oral maupun tertulis atau dengan keduanya sekaligus. Mubalig-mubalig kenamaan yang digandrungi masyarakat seperti K.H. Anwar Zahid dari Bojonegoro, Gus Muwafiq dan Gus Miftah dari Yogyakarta, misalnya, adalah beberapa contoh. Dalam tradisi tulis dan oral sekaligus nama Idrus Ramli layak diperhitungkan. Idrus Ramli telah menulis berbagai karya seperti Buku Pintar Berdebat dengan Wahabi, ${ }^{47}$ Kiai NU

\footnotetext{
${ }^{47}$ M. Idrus Ramli, Buku Pintar Berdebat dengan Wahabi (Surabaya: Bina Aswaja dan LBM NU Jember, 2012).
} 
atau Wababi yang Sesat tanpa Sadar, ${ }^{48}$ Hiøbut Tabrir dalam Sorotan, ${ }^{49}$ Membedah Bid'ah dan Tradisi dalam Perspektif Abli Hadits dan Ulama Salaf, ${ }^{50}$ Nur Hidayat Muhammad menulis Meluruskan Doktrin MTA, ${ }^{51}$ Ma'ruf Khozim, Jawaban Amaliyah \& Ibadah yang Dituduh Bid'ah, Sesat, Kafir dan Syirik,, ${ }^{52}$ dan lain-lain.

Tabel:

Agen Ideologi Kitab Kuning

\begin{tabular}{|c|c|c|c|}
\hline No & Agen & Deskripsi Agen & Modalitas \\
\hline \multirow[b]{4}{*}{1} & \multirow{4}{*}{$\begin{array}{l}\text { Agen } \\
\text { komunitas } \\
/ / \\
\text { kelompok }\end{array}$} & $\mathrm{NU}$ & \multirow{7}{*}{$\begin{array}{l}\text { 1. Modalitas } \\
\text { simbolik } \\
\text { keagamaan } \\
\text { 2. Modalitas } \\
\text { intelektual } \\
\text { 3. Modalitas } \\
\text { kader } \\
\text { 4. Modalitas } \\
\text { kultural } \\
\text { 5. Modalitas } \\
\text { historis } \\
\text { 6. Modalitas } \\
\text { jaringan } \\
\text { organisasional }\end{array}$} \\
\hline & & Komunitas Gusdurian & \\
\hline & & Pesantren & \\
\hline & & $\begin{array}{l}\text { Komunitas kultural seperti } \\
\text { Yasinan, Tablil, Dhiker al-Fidä, } \\
\text { Dhikr al-Ghāfilīn, Salawat } \\
\text { Nāriyah, dan lain-lain. }\end{array}$ & \\
\hline \multirow{3}{*}{2} & \multirow{3}{*}{$\begin{array}{c}\text { Agen } \\
\text { Individual }\end{array}$} & $\begin{array}{l}\text { Mubalig-Mubalig (Anwar } \\
\text { Zahid, Gus Muwafiq, Gus } \\
\text { Miftah, dan lain-lain). }\end{array}$ & \\
\hline & & $\begin{array}{l}\text { Penulis produktif (M. Idrus } \\
\text { Ramli, Ma'ruf Khozim, Nur } \\
\text { Hidayat Muhammad, dan lain- } \\
\text { lain). }\end{array}$ & \\
\hline & & $\begin{array}{l}\text { Tokoh-tokoh agama lokal } \\
\text { pemimpin ritual lingkaran } \\
\text { hidup. }\end{array}$ & \\
\hline
\end{tabular}

Para agen yang paling penting adalah pelaku-pelaku ritual pada tingkat lokal di masyarakat seperti kiai musala, pemimpin tablil, dan tokoh-tokoh lokal yang dengan konsisten melaksanakan ritual lingkaran hidup dengan sukarela sebagai bagian dari kehidupan sosial. Mereka hadir dengan sukarela untuk orang yang akan, sedang dan setelah melahirkan, kegiatan pra-pengantin, dan di saat dan pascakematian warga. Adapun modalitas yang dimiliki

${ }^{48}$ M. Idrus Ramli dan M. Syafiq Alydrus, Kiai NU atau Wahabi yang Sesat tanpa Sadar (Jember: Bina Aswaja, 2012).

${ }^{49}$ M. Idrus Ramli, Hizbut Tabrir dalam Sorotan (Surabaya: Bina Aswaja, 2011).

${ }^{50}$ M. Idrus Ramli, Membedah Bid'ah dan Tradisi dalam Perspektif Abli Hadits dan Ulama Salafi (Surabaya: Khalista, 2010).

${ }^{51}$ Nur Hidayat Muhammad, Meluruskan Doktrin MTA: Kritik atas Dakwah Majelis Tafsir al-Qur'an di Solo, Edisi Revisi (Surabaya: Muara Progressif, 2015).

52 Ma'ruf Khozim, Jawaban Amaliyah \& Ibadah yang Ditudub Bid'ah, Sesat, Kafir, dan Syirik (Surabaya: al-Miftah, 2013). 
agen yang bisa digunakan untuk memenangkan kontestasi adalah modalitas simbolik keagamaan, modalitas intelektual, modalitas kader, modalitas kultural, modalitas historis dan modalitas jaringan organisasional. Berikut adalah gambaran agen dan modalitas tersebut. Setiap ideologi, baik secara manifes maupun laten, sebenarnya sedang berkontestasi. Agen ideologi așhāab al-shäfíȳyah dalam kitab kuning yang mengandung keabsahan ritual lingkaran hidup harus memanfaatkan modal tersebut jika ingin memenangkan kontestasi dalam field terbuka, Indonesia.

\section{Penutup}

Pembahasan tentang ideologi kitab kuning yang menjadi legitimator terhadap pelaksanaan tradisi Islam Jawa ritual lingkaran hidup (life circle) dapat disimpulkan beberapa hal berikut. Pertama, pandangan kitab kuning terhadap tradisi ritual lingkaran hidup yang mewujud dalam ritual kelahiran (metu), pengantin (manten) dan kematian (mati) masuk dalam kategori pemahaman fiqh, yaitu bagian dari ijtihad manusia. Berbagai kitab kuning menyebut ritual lingkaran hidup telah dilaksanakan oleh Nabi Muhammad, sahabat atau tābi īn. Tradisi neloni dan mitoni (sebagai ritual kehamilan) misalnya dirujukkan kepada tindakan Nabi Muhammad dalam mendoakan Ummu Sulaym, istri dari Abū Țalḥah. Lebih dari itu, keumuman doa dan harapan slamet dapat memayungi segala aktivitas di dalamnya. Demikian pula masalah pencarian hari, baik dalam ritual manten tidaklah bertentangan dengan tawhìd, sehingga tidak mengakibatkan musyrik. Hal ini dituturkan oleh Ibn alFarkāh yang dinukil dari al-Shāfíì sebagaimanan dijelaskan oleh kitab kuning Ghäyat Talkhìs al-Murād min Fatāwā Ibn Ziyād. Ritualritual lain seperti manggulan atau kirim dongo adalah ritual yang masih dibenarkan karena bacaan-bacaan dari orang yang hidup masih dianggap bermanfaat bagi orang yang meninggal sebagaimana dijelakan oleh kitab kuning Fatāwà al-Ramlì. Keabsahan juga terjadi untuk ritual kematian. Ritual kematian menurut kitab kuning telah menjadi kebiasaan sebagian sahabat dan tābi īn sebagaimana dituturkan oleh Ṭāwūs dan 'Ubayd b. 'Umayr seperti yang dijelaskan dalam Fatāwà al-Fiqhiyah al-Kubrā karya Ibn Hajar alHaytamī.

Kedua, ideologi keagamaan kitab kuning yang mengabsahkan ritual lingkaran hidup Islam Jawa adalah ideologi al-Shāfíî yang 
dikembangkan oleh așhäb al-shäfí ỹyah. Tokoh-tokoh penting yang menjadi jalur transmisi kitab kuning tersebut di antaranya adalah al-Ghazāāi dan Muhy al-Dīn Abū Zakariyyā al-Nawawī. Melalui karya-karya mereka, berkembanglah tradisi așạab al-shäfi ìyah.

Ketiga, para agen mempertahankan ideologi al-shāfici yang dikembangkan oleh aș̣ab al-shäfíryah dengan cara berkomunitas atau berkelompok (agen kelompok atau lembaga) dan dengan cara individual (agen individual). Agen kelompok terdiri dari organisasi NU, komunitas Gusdurian, pesantren, komunitas-komunitas kultural seperti komunitas Yasinan, Tablïl, Dhikr al-Fidä, Zikrul Ghafilin, salawat Nariyah dan lain-lain. Melalui lembaga NU misalnya, ideologi al-Shāfíi dapat dipertahankan dalam jumlah organisasi di bawahnya, yaitu lembaga (14 lembaga), Banom (10 lembaga) dan Lajnah (2 lembaga). Demikian pula ideologi așhäb alshäfi'iyah dapat dipertahankan melalu kegiatan-kegiatan pesantren yang berjumlah sekitar 23.000 dengan jumlah santri sekitar 4.000.000. Untuk mempertahankan ideologi tersebut, para agen memiliki berbagai modal yang bisa digunakan untuk melakukan internalisasi sekaligus eksternalisasi ideologis. Modal tersebut adalah modalitas simbolik keagamaan, modalitas intelektual, modalitas kader, modalitas kultural, modalitas historis, dan modalitas jaringan organisasional.

\section{Daftar Rujukan}

'Ābidīn, Ibn. Radd al-Muhtär 'alā al-Durr al-Mukbtär, Vol. 2. Mesir: Muṣtafā al-Bāb al-Ḥalabī, 1966.

Anșārī (al), Abū Yahyāà Zakariyyā. Asnā al-Matālib fì Sharḅ Rawd alTaalib, Vol. 1. Beirut: Dār al-Kitāb al-Islāmī, t.th.

Anwar, M. Syafi'i. Pemikiran dan Aksi Islam Indonesia: Sebuah Kajian

Politik Cendekiawan Muslim Orde Baru. Jakarta: Paramadina, 1995.

Bā'alawī, 'Abd al-Raḥmān b. Muḥammad b. Husayn. Ghāyat Talkhìs al-Murād min Fatāwà Ibn Ziyàd. Beirut: Dār al-Fikr, t.th.

Bayhaqī (al), Abū Bakr Aḥmad. Daläill al-Nubuwwah, Vol. 6. Kairo: Dār al-Hadīth, t.th.

Baijūrī (al), Ibrāhīm. Tuhfat al-Murìd Sharh Jauhar al-Tawhịd. Beirut: Dār al-Kutub al-'Ilmīyah. 2004. 
Beatty, Andrew. Variasi Agama di Jawa: Suatu Pendekatan Antropologi, terj. Achmad Fedyani Saefuddin. Jakarta: PT. Raja Grafindo Persada. 2001.

Dimyāṭ̂̄ (al), Aḥmad b. Muhammad. Hạshiyah al-Dimyātì 'alā Sharh al-W araqät. Surabaya: al-Hidayah, t.th.

Dimyāṭ̣̂ (al), Muhammad Shatā. I'ánat al-Ṭälibìn, Vol. 1. Singapura: Sulaiman Mar'i. t.th.

Foucault, Michel. The Order of Things: An Archaeology of the Human Science. London: Tavistock Publication. 1974.

Geertz, Clifford. Abangan, Santri, Priyayi dalam Masyarakat Jawa. Jakarta: Pustaka Jaya. 1981.

Ghāzzī (al), Muḥammad b. Qāsim. Sharḥ Fatḥ al-Qarīb al-Mujīb. Surabaya: al-Hidayah, t.th.

Haytamī (al), Ibn Hajar al-Makkī al-Haytamī. Fatāwā al-Kubrā alFiqhiyah, Vol. 3. Mesir: 'Abd al-Hamīd Aḥmad Hanafì. t.th.

Hodgson, Marshal G. S. The Venture of Islam, Vol. 2. Chicago: University of Chicago Press, 1974.

Horikoshi, Hiroko. Kiai dan Perubahan Sosial. Jakarta: P3M, 1987.

Jāwī (al), Nawawī b. 'Umar. Kāshifat al-Sajā. Semarang: Usaha Keluarga. t.th.

Madjid, Nurcholish. Islam, Doktrin dan Peradaban: Telaab Kritis tentang Masalab Keimanan, Kemanusiaan, dan Kemodernan, cet. 4. Jakarta: Yayasan Paramadina, 2000.

Malībārī (al), Zayn al-Dīn. Fatḥ al-Mữnn. Beirut: Dār al-Kitāb alIslāmī, t.th.

Mulder, Niels. Agama, Hidup Sehari-hari dan Perubahan Budaya. Jakarta: Gramedia Pustaka Utama. 1999.

Nawawī (al), al-Jāwī, Muḥammad b. 'Umar b. 'Alī. Nihāyat al-Zayn Fì Irshäd al-Mubtadi'in. Bandung: Shirkat al-Ma'arif, t.th.

Oesman, Oetojo dan Alfian (eds.). Pancasila sebagai Ideologi dalam Berbagai Bidang Kehidupan Bermasyarakat, Berbangsa, dan Bernegara. Jakarta: BP-7 Pusat, 1991.

Ramlī (al), Shams al-Dīn Muḥmmad b. Abī al-'Abbās Aḥmad b. Hamzah b. Shihāb al-Dīn. Nihāyat al-Mubtāj ilā Sharh al-Minhāj, Vol. 2. Beirut: Dār al-Fikr, t.th.

Syam, Nur. Islam Pesisir. Yogyakarta: LKiS, 2005.

Tim Aswaja NU Center PWNU Jawa Timur. Khazanah Aswaja: Memahami, Mengamalkan dan Mendakwabkan Ablussunnab wal Jama'ah. Surabaya: Aswaja Center NU Ponorogo, 2016. 
Turmudi, Endang. Perselingkuhan Kiai dan Kekuasaan. Yogyakarta: LKiS, 2004.

Woodward, Mark R. (ed.). Jalan Baru Islam: Memetakan Paradigma Mutakbir Islam Indonesia, terj. Ihsan Ali-Fauzi, cet. 1. Bandung: Mizan, 1998.

Woodward, Mark R. Islam in Java: Normative Piety and Mysticism in the Sultanate of Yogyakarta. Ann Arbor: UMI, 1989.

Zaehner, R.C. Mistisisme Hindu Muslim, terj. Suhadi, cet. 1. Yogyakarta: LKiS, 2004. 